\title{
Yerel Düzeyde Katılımcı Mekanizmalar Olarak Kent Konseylerinin Bilinirlilik ve Etkinlik Düzeylerinin Analizi: Bursa Örneğí1
}

Elif KARAKURT TOSUN, Vocational School of Social Sciences, Uludag University, Turkey; e-mail: ekarakurt@uludag.edu.tr

Enes Battal KESKİN, Bursa City Council, Turkey; e-mail: keskinenes@gmail.com

Emel SELIMOĞLU, Vocational School of Social Sciences, Uludag University, Turkey; e-mail:

emels@uludag.edu.tr

\section{Efficiency Level Analysis of City Councils as Participating Mechanisms at Local Level: Bursa Example ${ }^{2}$}

\begin{abstract}
The research, in which recognition and effectiveness levels of city councils are handled, has two aims. First aim is: determining to what extent city councils and Bursa City Council are known by citizens living in city of Bursa and their information levels about the legal - administrative structures of city councils. Second aim is: Presenting to what extent the city councils fulfill the duties mentioned in the 76. article of municipality law and 6. article of city council legislation from the citizens' point of view. Based on the results obtained from field study conducted on 2915 people by face to face survey method, suggestions were made related with increasing recognition of city council by Turkish citizens and with performing their duties efficiently.
\end{abstract}

Keywords $\quad$ : City Councils, Bursa City Council, Governance.

JEL Classification Codes : $\quad$ H70, H79.

\section{$\ddot{\mathbf{O} z}$}

Kent konseylerinin bilinirliğinin ve etkinlik düzeyinin ele alındığı araştırmanın iki amacı bulunmaktadır. Birinci amac1: kent konseylerinin ve Bursa Kent Konseyi'nin, Bursa kentinde yaşayan vatandaşlar tarafindan ne oranda bilindiğinin tespit edilmesi ve Bursa'da yaşayan vatandaşların kent konseylerinin yasal - yönetsel yapısı hakkında bilgi düzeylerinin araştırılmasıdır. İkinci olarak; kent

I Bu çalışma Uludağ Üniversitesi Bilimsel Araştırmalar Birimi tarafindan desteklenen KUAP (SBMYO) 2013/89 nolu projenin sonuçlarından elde edilmişs olup 10-11 Nisan 2015 tarihinde gerçekleştirilen 2. Ulusal Kent Konseyleri Sempozyumu'nda sunulmuştur.

2 This study is derived from Project No. 2013/89 supported by Scientific Research Projects Commission of the Uludag University and the results of this project held on 10-11 April 2015 were presented at the $2^{\text {nd }}$ National Symposium of City Councils. 
konseylerinin Belediye Kanununun 76. maddesinde ve Kent Konseyi Yönetmeliğinin 6. maddesinde belirtilen görevleri ne oranda yerine getirdiğinin vatandaşların gözüyle ortaya konulmasıdır. Yüz yüze anket tekniğinin kullanıldığı ve 2915 kişiyle görüşmenin gerçekleştirildiği alan araştırmasından çıkan sonuçlardan hareketle Türkiye'de kent konseylerinin vatandaşlar tarafindan daha bilinir olabilmeleri ve görevlerini etkin bir şekilde yerine getirebilmeleri yönünde önerilerde bulunulmuştur.

\section{Anahtar Sözcükler $\quad$ : Kent Konseyleri, Bursa Kent Konseyi, Yönetişim.}

\section{Giriş}

Kent konseylerinin Türkiye'nin yerel yönetim anlayışında yeni bir mekanizma olması, kent konseylerinin bilinirliğinin ve etkinliğinin önündeki en büyük engellerinden birisidir. Yöneten - yönetilen ekseninde şekillenen klasik yönetim anlayışının birden bire değişmesi elbette düşünülemez. Vatandaşların yerel düzeyde karar alma süreçlerine aktif katılımı için oluşturulan kent konseyleri, 2005 tarihli Belediye Kanununun 76. maddesiyle ülkedeki tüm belediyeler için kurulması zorunlu bir mekanizma haline gelmiştir.

2005 yilından önce Türkiye'de belediyelerin kendi inisiyatifleri ile kurmuş oldukları ve yerel halkın yönetsel süreçlere daha aktif katılımını amaçlayan kent konseyleri mevcuttu. Bu kent konseyleri daha çok belediye başkanlarının kişisel inisiyatifiyle oluşturulmuştur. Sayıları oldukça az olan bu kent konseyleri, işlevlerini yerine getirme konusunda zaman zaman sıkıntılar yaşasa da, varlıklarını günümüze kadar devam ettirebilmiş konseylerdir.

Belediye Kanunu ile birlikte yerel halkın yönetim süreçlerine dâhil olmasını kolaylaştıran bir mekanizma olarak kent konseylerinin kurulması belediye başkanlarının inisiyatifinden çıkarak bir zorunluluk haline gelmiştir. Fakat kanunun çıkmasının üzerinden 10 yil geçmesine rağmen, ülkedeki tüm belediyelerde kurulmuş ve sistemli bir şekilde işleyen kent konseyleri mevcut değildir. Diğer yandan bazı belediyeler ise yasal zorunluluk olduğu için kendi bünyelerinde kent konseyleri kurmuştur fakat bu konseyler sadece kâğıt üzerindedir, herhangi bir faaliyetleri yoktur. Bu anlamda birçok kentte kent konseyi, yasak savma kabilinden kurulmakta, daha da önemlisi kent konseyi halk tarafindan bilinmemektedir.

2005 yılındaki Belediye Kanunundan 10 yıl önce, 1995 yılında temelleri atılan Bursa Kent Konseyi ülkede kurulmuş olan ilk kent konseylerinden birisidir. Kentte çok sayıda kültür- sanat faaliyetleri düzenlemekte, bilimsel organizasyonlara ev sahipliği 
yapmakta ve "Bursa Konuşuyor" teması ile kentin önemli sorunlarının görüşüldüğü genel kurul toplantıları düzenlemektedir. Bu anlamda oldukça faal bir kent konseyidir ${ }^{3}$.

$\mathrm{Bu}$ çalışmada, yerel halkın yönetsel süreçlere daha aktif dâhil olması yoluyla kentin ortak aklı olması hedeflenen kent konseylerinin, yönetişim olgusunun diğer aktörlerinden olan vatandaşlar gözüyle irdelenmesi amaçlanmıştır. Söz konusu çalışmanın iki temel hedefi vardır. İlk olarak Bursa kenti özelinde, vatandaşlar tarafindan kent konseylerinin ne oranda bilindiklerinin tespit edilmesidir. İkinci olarak ise kent konseylerinin 5393 Sayılı Kanunda ve Kent Konseyleri Yönetmeliğinde verilen görevleri yerine getirmedeki etkinlik düzeylerinin vatandaşların gözüyle ortaya konulmasıdır. Bu iki hedefe ulaşabilmek amacıyla Bursa'nın yedi ilçesinde bir alan araştırması yürütülmüştür. Yüz yüze anket tekniğinin kullanıldığı alan araştırmasında 2915 kişi ile görüşülerek kent konseylerinin bilinirlilik oranı ve etkinlik düzeyleri ayrıntılı olarak incelenmiştir.

\section{Türkiye'de Kent Konseylerine Genel Bakış}

Türkiye'de kent konseylerinin yapısal olarak ortaya çıkışı Yerel Gündem 21 (YG 21) çalışmalarına dayanmaktadır. Bu nedenle Türkiye'de kent konseylerine ilişkin yapılacak tüm değerlendirmeler öncelikle Yerel Gündem 21'e dayandırılmalıdır. Bu anlamda kent konseyleri, Türkiye'de Yerel Gündem 21 yaklaşımının uygulama modeli olarak oluşturulmuştur (Karakurt Tosun \& Keskin, 2015: 363).

YG 21 sürecinin temel kavramının sürdürülebilirlik olduğu göz önünde bulundurulduğunda, bu kavramın küresel düzlemde yaygınlaşması 5 Haziran 1972'de Stockholm'de yapılan Birleşmiş Milletler İnsan Çevresi Konferansı'na dayanmaktadır. Stockholm Bildirgesi'nde, çevrenin taşıma kapasitesine dikkat çeken, kaynak kullanımında kuşaklar arası hakkaniyeti gözeten, ekonomik ve sosyal gelişmenin çevre ile bağlantısını kuran ve kalkınmayla çevrenin birlikteliğini vurgulayan ilkeler, sürdürülebilir kalkınma kavramının temel dayanaklarını ortaya koymaktadır. Bu kavram 1987 yılında Dünya Çevre ve Kalkınma Komisyonu tarafından, yayınlanan Ortak Geleceğimiz Raporunda tanımlanmıştır. Giderek ağırlaşan çevresel sorunlar karşısında, insanlığın çıkış yolu olarak, çevresel gelişme ile ekonomik kalkınma arasındaki yaşamsal köprünün kurulması ve gelişmenin sürdürülebilir olması, bu raporda oldukça detaylı bir şekilde ele alınmıştır (UN, 1991).

1992'de Rio'da gerçekleştirilen Birleşmiş Milletler Çevre ve Kalkınma Konferansı ile hayat bulan Gündem 21, sürdürülebilir kalkınma hedeflerine ulaşma

32015 yılına kadar çarpık kentleşme, trafik tıkanıklı̆̆l, deprem, sıcak su kaynaklarl, çevre yolu, sanayi bölgeleri hızlı tren, çevre yolu, vb. konularında 74 adet genel kurul toplantısı düzenlenmiştir. Bu toplantılar gerçekleştirilmeden sonra gerek billboardlar yoluyla gerek yerel yazıl-sözlü medya yoluyla halka yeri ve zamani ilan edilmektedir. 
noktasında küresel bir eylem planı olarak nitelendirilmektedir. Dört ana ve bir tamamlayıcı kısımdan oluşan Gündem 21 'in yerel yönetimler ile ilişkisine bakıldığında, “Gündem 21 'in Desteklenmesinde Yerel Yönetim Girişimleri” başlıklı 28. bölüm ön plana çıkmaktadır. YG 21 kavramının dile getirildiği bu bölümde, yerel yönetimlerin öncülüğünde sivil toplumun ve diğer tüm ilgililerin birlikte kendi sorunlarını ve önceliklerini saptayarak, kentleri için 21. Yüzyılın Yerel Gündemini oluşturmaları karara bağlanmıştır ${ }^{4}$. Böylece her ülke uygulayıcı mekanizmaları ve ilkeleri ile kendilerine özgü YG 21 yapılarını oluşturmaya çağrılmıştır. Ülkeler kendi YG 21 süreçlerini uygularken, vatandaşların sürece aktif katılımını da ilke olarak benimsemişlerdir. Bu durum YG 21 'in temel amacını sürdürülebilirlik olarak ön plana çıkartırken bu çerçevede kullanılacak araç ise yönetişim olmaktadır.

YG 21 Eylem Programı, 1992 yılından bu yana, yaklaşık 135 ülkedeki yüzlerce kentte uygulanmaktadır. Gündem 21 'in dünya ölçeğindeki koordinatör kuruluşu olan UNDP - Birleşmiş Milletler Kalkınma Programı, aralarında Türkiye’nin de bulunduğu 85 ülkede, YG 21 süreçlerini desteklemiştir.

YG 21 ekseninde sürdürülebilir gelişme ve yönetişim ilkelerinin hangi araçlarla ve hangi politikalarla uygulanacağı ülkelerin geliştirecekleri modellere göre farklılaşmıştır. Her ülkede kendilerine özgü ve toplumsal yapılarının gereklerine uygun bir toplumsal uzlaşma modeli tartışılmaya, şekillenmeye başlamıştır.

Türkiye'deki YG 21 süreci ise şu şekilde gelişmiştir. 1997 yılında, IULA-EMME Uluslararası Yerel Yönetimler Birliği, Doğu Akdeniz ve Ortadoğu Bölge Teşkilatı koordinatörlüğünde yürütülen Türkiye'de Yerel Gündem 21 'lerin Teşviki ve Geliştirilmesi ${ }^{5}$ projesi başlamıştır. Projenin birinci yılı sonunda projenin uygulandığı kent sayısı 23 'e çıkartılmıştır ${ }^{6}$. Bakanlar Kurulu'nun kararıyla başlatılan proje, 1999'da tamamlanmıştır. Bu projenin başarısı üzerine UNDP, ikinci aşamaya da destek vermeyi kabul etmiştir. Türkiye'de Yerel Gündem 21'lerin Uygulanması başlığını taşıyan ikinci aşama projesi, 2000 'de başlamıştır. İkinci aşamada proje ortağı yerel yönetimlerin sayısının 50'yi aşması

Daha geniş bilgi için bkz. <http://www.un-documents.net/a21-28.htm>, 25.06.2015.

5 Bu proje Türkiye'de 9 kenti kapsamaktadır. Bu kentler: Bursa, İmir ve Antalya Büyükşehir Belediyeleri ile Adıyaman, Ağrı, Çanakkale, Gölbaşı (Ankara), Harran (Şanlıurfa) ve Trabzon'dur.

6 Sonraki 14 kent Diyarbakır, Gaziantep ve Kocaeli Büyükşehir Belediyeleri ile Afyon, Aliağa (İzmir), Burdur, Çatalca (İstanbul), Çeşme (İzmir), Çorum, Foça (İzmir), Kaş (Antalya), Kızkalesi ('̇çel), Zonguldak Belediyeleri ve Kastamonu Il Özel İdaresi'dir.

7 Bu projeye dâhil olan kentler ve belediyeler ise şu şekildedir: Adana, Adapazarl, Antalya, Bursa, Diyarbakır, İzmir, İzmit, Mersin, Samsun ve Eskişehir Büyükşehir Belediyesi; Edirne, Kastamonu ve Nevşehir İ Özel İdaresi; Afyon, Ağgrı, Antakya, Aydın, Bolu, Burdur, Çanakkale, Çorum, Denizli, Kars, Kütahya, Malatya, Mardin, Muğla, Van, Yalova ve Zonguldak il merkez ilçe belediyeleri; Doğubeyazıt (Ă̆rn), Yenimahalle (Ankara), Kuşadası (Aydın), İznik, Nilüfer ve Orhangazi (Bursa), Yalvaç (Isparta), Silivri (İstanbul), Aliağa, Çeşme, Foça, Karaburun ve Ödemiş (İzmir), Babaeski (Kırklareli), Bekirpaşa, Değirmendere, Gebze ve Gölcük (Kocaeli), Tarsus (Mersin), Ürgüp (Nevşehir), Harran ve Yaylak (Şanlıurfa) ilçe/belde belediyeleridir. 
sonrasında, YG 21 uygulamaları proje çerçevesinden çıkarılarak, uzun dönemli bir programa dönüştürülmüştür (Soygüzel, 2012; Soygüzel, 2015).

Türkiye'de YG 21 Programı çerçevesinde gerçekleştirilen çalışmalara paralel olarak çeşitli kentlerde kent meclisi, kent parlamentosu, kent kurultayı, vb. adlarla kurulmuş ve birbirinden farklı organlara - çalışma yapısına sahip katılımcı mekanizmalar ortaya çıkmıştır. YG 21 Programı ortağı kentlerde kurulmuş olan bu katılımcı mekanizmalar, 5393 sayılı Belediye Kanunu ile birlikte kurulan kent konseylerine destek olmuş ve çalışmaların ülke ölçeğinde yaygınlaşmasına öncülük etmiştir.

2005 tarihli 5393 Sayılı Belediye Kanununun 76. maddesinde kentsel yapıda yerel katılımın arttırılmasını sağlayacak bir mekanizma olarak kent konseylerine ilişkin olarak yapılan kısa tanımlamadan sonra kent konseylerinin çalışma usul ve esaslarının, İçişleri Bakanlığınca hazırlanacak yönetmelikle belirleneceği belirtilmiştir.

İlgili yönetmelik 08.10.2006 tarihli Resmi Gazete'de yayınlanarak yürürlüğe girmiş, 2009'da ise değişikler yapılmıştır.

Kent Konseyleri Yönetmeliğinin 1. maddesinde “... kent yaşamında, kent vizyonunun ve hemşerilik bilincinin geliştirilmesi, kentin hak ve hukukunun korunması, sürdürülebilir kalkınma, çevreye duyarlılık, sosyal yardımlaşma ve dayanışma, saydamlık, hesap sorma ve hesap verme, katılım, yönetişim ve yerinden yönetim ilkelerini hayata geçirmeye çalışan” bir kuruluş olarak kent konseyleri tanımlanmaktadır.

Kent Konseyi Yönetmeliğinin kent konseyinin oluşumunu anlattığı 5 . maddesinde; "Kent Konseyleri belediye teşkilatı olan yerlerde, mahalli idareler genel seçim sonuçlarını izleyen 3 ay içinde, 8 inci maddede belirtilen üyelerden oluşur, kent konseyi genel kurulu ilk toplantısını yapmak üzere belediye başkanının çağrısı ile toplanır” denilmek suretiyle, kent konseylerinin belediye olan her yerde kurulacağ belirtilmektedir.

2015 y1lı itibariyle, Türkiye'de 30 büyükşehir belediyesi, 51 il belediyesi, 519 büyükşehir ilçe belediyesi, 400 ilçe belediyesi ve 396 belde belediyesi olmak üzere 1.396 belediye bulunmaktadır ${ }^{8}$. Teorik olarak; 1.396 belediye olduğuna göre, 1.396 kent konseyi de kurulmuş olmalıdır. Uygulama da ise durum oldukça farklıdır; ilçe ve belde belediyelerini hiç dikkate almasak bile, 20 civarında büyükşehir ve il belediyesinde kent konseyi hala kurulmamıştır. Daha ilginç olanı ise, Türkiye'de kurulmuş kent konseyi sayısının net olarak bilinmiyor olmasıdır. Tahmini bilgilere göre; ülkemizde hali hazırda kurulmuş bulunan kent konseyi sayısı toplam belediye sayısının \%10’u civarında ve yaklaşık 150'dir'. 
Kurulması kanunla emredildiği halde, ülkenin bazı belediyelerinde kent konseylerinin kurulmuyor olması açıklanması zor bir durumdur. Başka bir açıdan, kent konseyleri belirli bir demokratik kültürel altyapının sonucunda oluşturulabilecek bir platformlardır. Bir diğer ifade ile kent konseylerinin çalışmalarının temel muhatabı ve aktörü konumunda olan bireylerin (vatandaşların) bu yapının içinde önemli görevleri bulunmaktadır. Kent konseyleri ancak demokrasiyi içselleştiren, kent halkını karar alma süreçlerine katması gerektiğine inanan yöneticilerin olduğu kentlerde işlevlerini yerine getirebilirler. Diğer yandan kentte yaşayanların da; kentine sahip çıkan ve kentin sorunlarını çözmek için yönetsel süreçlere aktif olarak katılan bireyler olması gerekmektedir. Kent konseyleri, kentine sahip çıkan kısaca kentlilik bilinci gelişmiş bireylerin olduğu kentlerde etkin bir şekilde çalışmalarını gerçekleştirebilir (Keskin, 2014: 58).

\section{Bursa Kent Konseyi}

Bursa Kent Konseyi, hem yerel bir hareket, hem de uluslararası sürecin bir parçası olarak doğmuştur Yerelde; önce birkaç mahallenin ortaklaşa merkezi biçiminde, mahalle sorunlarının tartışıldığı, çözüm önerilerinin getirildiği, vatandaş yerel yönetim ilişkilerinin kolaylaştırıldığı, katılımcı yönetim birimleri olarak, Semt Danışma ve Dayanışma Merkezleri (SEDAM) kurulmuştur. SEDAM'larda başlatılan katılımcı sürecin devamında kentin tümünü kapsayan bir katılımcılığı hayata geçirmek üzere Şehir Danışma ve Dayanışma Konseyi oluşturulmuştur. Yani çoğulcu ve katılımeı çabalar ile vatandaş belediye işbirliği, tabandan tavana bir yerel örgütlenme modeli ortaya çıkarmıştır. Diğer yandan Bursa, Birleşmiş Milletler Gündem 21 küresel konseptinin bir bakıma yerel izdüşümü olan Yerel Gündem 21 Programı'na, Türkiye'nin bu programı hükümet düzeyinde desteklemesinden önce eklemlenerek, Kent Konseyi sürecini uluslararası işbirliği ile desteklemiştir (Bulut, 2013: 91).

1995 y1lı başlarında Bursa Büyükşehir Belediyesi'nin girişimiyle oluşturulan Şehir Danışma ve Dayanışma Konseyi, 3 ayda bir toplanan ve 104 üye ile çalışan Konsey’de; yerel yönetimler, kamu kurum ve kuruluşlarının temsilcileri, meslek odaları, demokratik kitle örgütleri, sivil toplum kuruluşlarının temsilcileri ile daha önceki yıllarda Bursa'ya vali ve belediye başkanı düzeyinde hizmet eden eski yöneticiler yer almıştır. Konsey, 1998 yılında yeniden yapılanarak Bursa Kent Konseyi platformuna dönüşmüştür (Bursa Yerel Gündem 21, 2008: 10-17).

Diğer yandan, 1995 yılında Roma’da gerçekleştirilen “Akdeniz Yerel Gündem 21" toplantısına katılan dönemin Bursa Büyükşehir Belediye Başkanı Erdem Saker, Yerel Gündem 21 (YG-21) uygulamasını benimseyerek Bursa'ya taşımıştır. Çalışmaları koordine etmek üzere, aynı yıl Bursa Yerel Gündem 21 Genel Sekreterliği oluşturulmuştur. Bursa Yerel Gündem 21 Genel Sekreterliği ile eşgüdüm içerisinde çalışmak amacıyla; 1996 yılında Büyükşehir Belediye Meclisi'nde alınan bir kararla, Yerel Gündem 21 Şube Müdürlüğü kurulmuştur (Bursa Yerel Gündem 21, 2008: 10-11). 
1995 y1lında temelleri atılan Bursa Kent Konseyi, yerel karar alma mekanizmalarına halkın katılımı bağlamında Yerel Gündem 21 sürecinde işlevsel bir şekilde çalışmış, 2005 yılında çıkarılan 5393 Sayılı Belediye Kanunu ve bu kanun çerçevesinde yayımlanan Kent Konseyi Yönetmeliği hükümleri gereğince, Yerel Gündem 21 çalışmaları da Kent Konseyi bünyesine taşınarak farklı bir sürece girmiştir. Bursa Yerel Gündem 21 Genel Sekreterliği bünyesindeki faaliyetler, 2009 y1lından itibaren Bursa Kent Konseyi çatısı altına alınarak sürdürülmektedir ${ }^{10}$.

Bugüne kadar 74 gündemli genel kurul toplantısı yapmış olan Bursa Kent Konseyi; çarpık kentleşmeden hava kirliliğine, depremden hızlı trene, fuar alanından kent meydanına, sıcak su kaynaklarından çevre yoluna kadar, kenti/kentliyi ilgilendiren önemli pek çok konuda ortak aklı harekete geçirmiş görünmektedir ${ }^{11}$.

\section{Kent Konseylerinin Bilinirliliği Ve Etkinlik Düzeyi Araştırması}

Kent konseylerinin bilinirlik ve etkinlik düzeyinin ele alındığı bu çalışmanın iki amacı bulunmaktadır:

Birinci amac1: kent konseylerinin ve Bursa Kent Konseyi'nin, Bursa kentinde yaşayan vatandaşlar tarafından ne oranda bilindiğinin tespit edilmesi ve Bursa'da yaşayan vatandaşların kent konseylerinin yasal - yönetsel yapısı - çalışma alanları, vb. konulardaki bilgi düzeylerinin ortaya konulabilmesidir.

İkinci amacı ise; Türkiye'de yerel halkın yönetsel süreçlere dâhil olarak yerel kararlarda söz sahibi olabilmesi amacıyla tüm belediyeler için kurulması yasal zorunluluk olarak kabul edilen kent konseylerinin Belediye Kanununun 76. maddesinde ve Kent Konseyi Yönetmeliğinin 6. maddesinde belirtilen görevleri ve kendisine yüklenen misyonu ne oranda yerine getirdiğinin vatandaşların gözüyle ortaya konulmasını sağlamaktadır.

Bilindiği üzere, kent konseylerinin işlevsellik kazanması ancak vatandaşlar tarafından bilinip sahip çıkılmasıyla mümkündür. Kent halkı tarafından bilinmeyen bir kent konseyi, yasak savmak kabilinden kurulmuş bir kent konseyinden öte bir anlam taşımaz.

Kent konseylerinin ve Bursa Kent Konseyi'nin bilinirliği - etkinlik düzeyinin araştırılması, Bursa Büyükşehir Belediyesi sınırları içinde yer alan Osmangazi, Yıldırım, Nilüfer, Gemlik, Mudanya, Gürsu ve Kestel ilçelerinde gerçekleştirilmiştir. Hedef ana kütlenin geniş kapsamlı ve heterojen bir yapıya sahip olması nedeniyle tam sayım yapmak

10 Daha geniş bilgi için bkz. <http://www.bursa.bel.tr/yerel-gundem-21-calismalari---bursa-kent-konseyi-olarak-devam-edecek/haber/1464/>, 05.03.2015.

11 Daha geniş bilgi için bkz. <bursakentkonseyi.org.tr>, 05.03.2015. 
mümkün değildir. Bu nedenle araştırmada örneklem kütlesi mümkün olduğunca büyük tutulmaya çalışılmıştır. Söz konusu örneklem kütlesinin seçilmesinde, söz konusu ilçelerde yaşayan ve ilçe içerisinde farklı sosyal ve kültürel özelliklere sahip olan birimlerin araştırmaya dâhil edilmesi hedeflenmiştir. Araştırma kapsamında yer alan ilçelerin nüfusları dikkate alınarak "Tabakalı Rastgele Örnekleme Yöntemi” tercih edilmiştir.

Kent konseylerinin ve Bursa Kent Konseyi’nin bilinirliğinin - etkinliğinin ele alındığı alan araştırmasına dayalı bu araştırma, Bursa Büyükşehir Belediyesi sınırlarındaki 7 ilçede Ocak - Şubat 2015 tarihlerinde gerçekleştirilmiştir. Alan araştırması Uludağ Üniversitesi Bilimsel Araştırmalar Birimi tarafından desteklendiği için, sahada hizmet satın alma yöntemiyle bir anket şirketi ile çalışılmıştır. Proje yürütücüsünün ve ekibinin koordinatörlüğünde ve denetiminde gerçekleştirilen alan araştırmasında, Bursa kentinin merkezi ilçeleri olan Nilüfer, Yıldırım, Osmangazi, Mudanya, Gemlik, Gürsu ve Kestel’de yaşayan halkın genel profilini yansıtacak cinsiyet dağılımı, eğitim ve gelir düzeylerine ulaşabilmek amacıyla, bu ilçelerin merkezi lokasyonları tespit edilerek alan araştırmasına başlanılmıştır. Alan araştırması, çalışan ve çalışmayan tüm kesimler göz önünde bulundurularak Cuma-Cumartesi -Pazar - Pazartesi günleri saat 10:00 ile 19:00 saatleri arasında gerçekleştirilmiştir.

Araştırma kapsamında 2915 denekle yüz yüze görüşülerek doldurulan anket formunda toplam 60 adet soru bulunmaktadir.

Kent konseylerinin ve Bursa Kent Konseyi’nin Bilinirliği ve Etkinlik Düzeyinin araştırıldığı bu araştırmada oluşturulan anket formu üç bölümden oluşmaktadır. Bunlar aşağıdaki gibidir:

- Demografik bilgileri tespit etmeye ilişkin sorular,

- $\quad$ Kent Konseyleri ve Bursa Kent Konseyi adlı kurumun varlığından haberdar olma ve kent konseylerinin yasal - yönetsel - mali yapıları - çalışma alanları, vb. hakkındaki bilgilerin tespitine yönelik sorular,

- $\quad$ Türkiye'deki kent konseylerinin genel olarak etkinliğini ölçmeye yönelik sorular şeklindedir.

Söz konusu bölümlerden kent konseylerinin etkinliğine yönelik veriler 5 'li likert tarzı sorulardan oluşmaktadır. Bu bölüme ilişkin hesaplanan Cronbach-Alfa değeri aşağıdaki tabloda yer almaktadir.

Tablo: 1

Cronbach $\alpha$ Değerleri

\begin{tabular}{|l|c|c|c|}
\hline Boyutlar & Madde & Ort & C.Alpha \\
\hline Kent Konseylerinin Etkinliği & 10 & 3,67 & 0,86 \\
\hline
\end{tabular}




\section{Araştırmanın Bulguları}

Kent konseylerinin bilinirliğinin ve etkinlik düzeyinin araştırıldığı ve yüz yüze görüşme yoluyla gerçekleştirilen alan araştırmasına ilişkin veriler aşağıdaki gibidir:

\subsection{Demografik Bulgular}

Alan araştırmasına katılan bireylerin demografik özellikleri şu şekildedir: katılımcıların \%33,1'i kadın \%66,9'u erkektir. Araştırmaya katılan bireylerin eğitim durumuna bakıldığında; en yüksek iki oran $\% 55,5$ ile orta öğretim ve $\% 24,9$ ile üniversitedir. Katılımcıların medeni durumları ise; \%60,4 evli ve \%37,2 bekârdır. Dul/boşanmışların oranı ise \%2,4'tür. Katılımcıların \%92,8'inin herhangi bir STK'ya üye değildir.

\subsection{Kent Konseyleri Hakkındaki Bilgi Düzeyine İlişkin Bulgular}

Alan araştırmasına dâhil olan katılımcıların, yönetim kültüründe yeni bir anlayışı ifade eden kent konseyleri hakkında ne düzeyde bilgi sahibi olduklarını tespit etmeye yönelik genel nitelikte bazı sorular sorulmuştur. Bu bağlamda Bursalı vatandaşlara ilk olarak kent konseyinden haberdar olup olmadıkları sorusu yöneltilmiş, alınan cevaplar Tablo 2'de sunulmuştur. Buna göre katılımcıların \% 73,2'lik büyük bir kısmı kent konseyini duyduğunu belirtmiştir. Kent konseyinden haberdar olmayanların oranı ise \%26,8'dir. Kent konseyleri kurumunu daha önceden hiç duymadıklarını belirten 782 kişi ile soruların tamamının kent konseyleriyle ilgili olması nedeniyle anket çalışması sonlandırılmıştır, soruya evet cevabını veren 2132 kişi ile çalışmaya devam edilmiştir.

Tablo: 2

Kent Konseyini Duydunuz Mu?

\begin{tabular}{c|c|c} 
& Frekans & \% \\
\hline Evet & 2132 & 73,2 \\
\hline Hayır & 782 & 26,8 \\
\hline Toplam & $\mathbf{2 9 1 5}$ & $\mathbf{1 0 0 , 0}$
\end{tabular}

Anket çalışmasında bireylerin kent konseylerinin yasal yapısı hakkında ne oranda bilgi sahibi oldukları araştırılmıştır. Bursa'da yaşayan ve anket çalışmasına dâhil olan bireylerin kent konseylerinin kurulmalarının zorunlu olduğunu bilip bilmediklerini öğrenebilme amacıyla yöneltilen soruda katılımcıların \%51'i kent konseylerinin kurulmasının isteğe bağlı olduğunu düşünmektedir. Zorunlu olduğunu düşünenlerin oranı ise \%18,8'dir. Fikrim yok seçeneğinin \%30,2 düzeyinde olması ise, kent konseylerinin toplumun gündemine tam olarak girmediğinin bir göstergesi olarak okunabilir. (Bkz. Şekil $1)$. 


\section{Tablo: 3}

Kent Konseylerinin Kurulması Yasal Bir Zorunluluk Mudur?

\begin{tabular}{l|c|c} 
& Frekans & \% \\
\hline Yasal zorunluluktur. & 400 & 18,8 \\
\hline İsteğe bağlıdır. & 1086 & 51 \\
\hline Fikrim yok. & 646 & 30,2 \\
\hline Toplam & $\mathbf{2 1 3 2}$ & $\mathbf{1 0 0 , 0}$
\end{tabular}

Şekil: 1

Kent Konseylerinin Yasal Statüsü

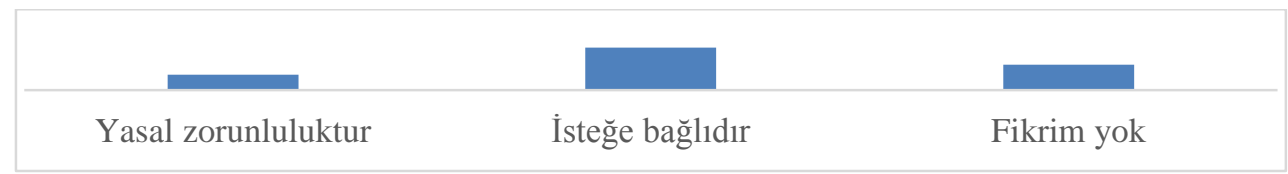

Kent konseylerinin yasal statüleriyle ilintili olarak alan araştırmasında katılımcılara, "Türkiye'nin tüm illerinde kent konseyi kurumu bulunmakta mıdır?” şeklinde bir soru sorulmuştur. Tablo 3’te görüldüğü üzere sadece \%35,5 oranında kişi hayır cevabını verirken, \%24,1'i evet ve \%40,4'ü fikrim yok cevabını vermiştir. Katılımcıların büyük bir kısmı kent konseyi kurumunu daha önceden duymuşlardır fakat kent konseyleri kurumunun ülkenin tüm illerinde olmadığının farkında değillerdir. Bu durum Şekil 2'de de görülmektedir.

Tablo: 4

Türkiye'deki Tüm IIllerde Kent Konseyi Bulunmakta Mıdır?

\begin{tabular}{l|c|c} 
& Frekans & \% \\
\hline Evet & 514 & 24,1 \\
\hline Hayır & 757 & 35,5 \\
\hline Fikrim yok & 861 & 40,4 \\
\hline Toplam & $\mathbf{2 1 3 2}$ & $\mathbf{1 0 0 , 0}$
\end{tabular}

Şekil: 2

Türkiye'deki Tüm İllerde Kent Konseyinin Varlığı

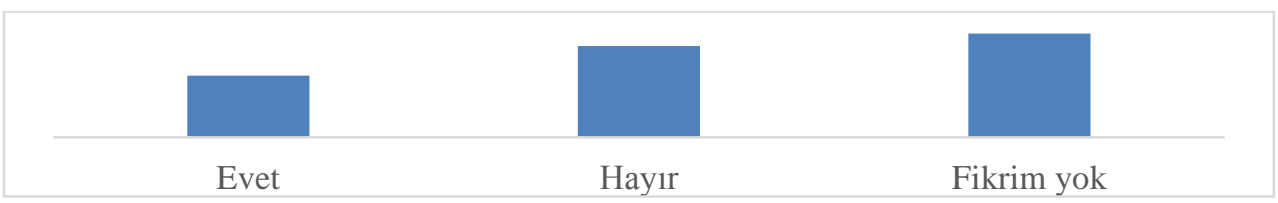

"Kent konseyinin yönetsel yapısı nasıldır?" sorusuna verilen cevaplar Tablo 5'de görülmektedir. Buna göre; kent konseyi bir sivil toplum kuruluşudur, diyenler ilk sıradadır ve oranları $\% 32,4^{\prime}$ tür. Kent konseyi bir belediye kuruluşudur, diyenlerin oranı $\% 25,2$ 'dir. 
Kamu kuruluşudur, diyenler \%8,0, özel sektör kuruluşudur, cevabını verenler ise \%3,8 düzeyindedir.

Tablo: 5

Kent Konseyinin Yasal / Yönetsel Yapısı Nasıldır?

\begin{tabular}{l|c|c} 
& Frekans & \% \\
\hline Kamu kuruluşudur. & 171 & 8,0 \\
\hline Sivil toplum kuruluşudur. & 692 & 32,4 \\
\hline Özel sektör kuruluşudur. & 81 & 3,8 \\
\hline Belediye kuruluşudur. & 537 & 25,2 \\
\hline Hiçbirisi & 26 & 1,2 \\
\hline Fikrim yok & 625 & 29,3 \\
\hline Toplam & $\mathbf{2 1 3 2}$ & $\mathbf{1 0 0 , 0}$
\end{tabular}

Şekil 3'te bu soruya katılımcıların verdikleri cevapların dağılımları şekil yardımıyla gösterilmiştir.

Şekil: 3

\section{Kent Konseylerinin Yasal / Yönetsel Yapısı}

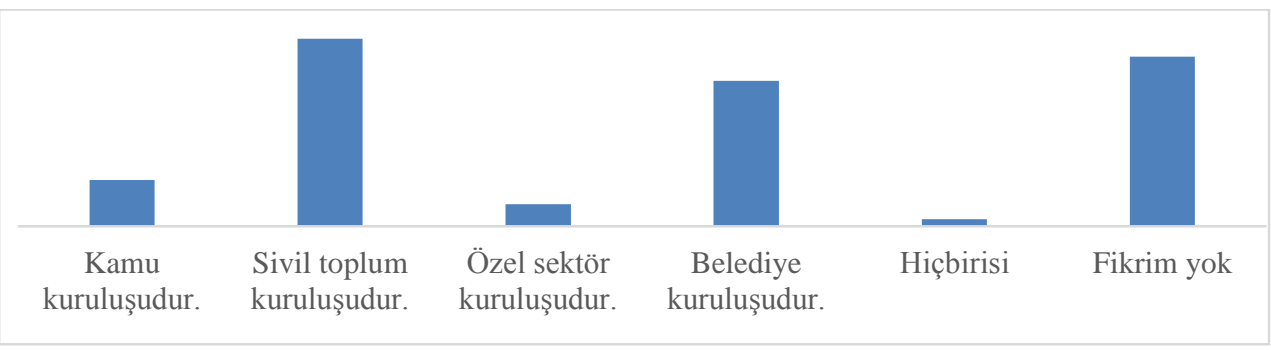

Araştırma kapsamında kent konseyi genel kurulunun kimlerden oluştuğu sorulduğunda ise katılımcılar, bu soruya büyük oranda $(\% 42,8)$ "fikrim yok" cevabını vererek, bu konuda bilgi sahibi olmadıklarını ifade etmektedirler.

Tablo: 6

Kent Konseyi Genel Kurulu Kimlerden Oluşmaktadır?

\begin{tabular}{|c|c|c|}
\hline & Frekans & $\%$ \\
\hline Kamu kurumu ve muhtarlık temsilcileri & 149 & 7,0 \\
\hline Siyasi parti ve STK temsilcileri & 241 & 11,3 \\
\hline Üniversite temsilcileri & 47 & 2,2 \\
\hline Gönüllü temsilcileri & 351 & 16,5 \\
\hline Hepsi & 471 & 22,1 \\
\hline Fikrim yok & 911 & 42,8 \\
\hline Toplam & 2132 & 100,0 \\
\hline
\end{tabular}


Şekil 4'te de görüldüğü üzere kent konseyi genel kurulunun kimlerden oluştuğu sorulduğunda \%42,8 oranında fikrim yok, cevabı verilmiştir.

Şekil: 4

Kent Konseyi Genel Kurulunun Kimlerden Oluştuğu

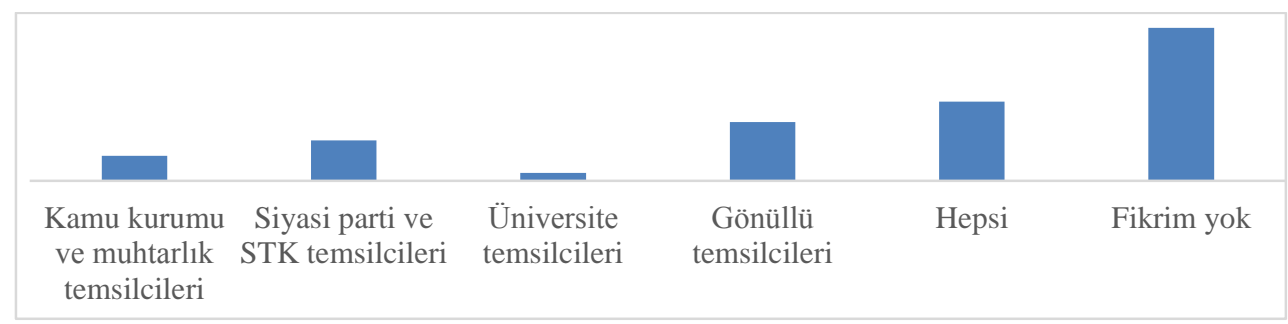

Kent konseyleri ile ilgili temel konulardan bir tanesi de kent konseyinin bütçesinin hangi kaynaktan oluştuğudur. Kent konseylerinin bütçelerinin nasıl oluşturulacağına ilişkin ilgili yönetmelikte hiçbir hüküm yoktur. Kent konseylerine bağl1 bulundukları belediyeden doğrudan kaynak sağlanmaktadır. Kent konseylerinin bütçeleri ile ilgili bu soruya doğru cevap verenlerin oranı $\% 33,4$ düzeyinde kalmıştır.

Tablo: 7

Kent Konseylerinin Çalışmalarına Temel Teşkil Eden Bütçenin Kaynağı Nedir?

\begin{tabular}{l|c|c} 
& Frekans & \% \\
\hline Doğrudan merkezi yönetimden (İçişleri Bakanlı̆̆ı) gelmektedir. & 81 & 3,8 \\
\hline Belediye bütçesinden pay ayrılmaktadır. & 713 & 33,4 \\
\hline Bağı̧ ve yardımlardan destek sağlanmaktadır. & 192 & 9,0 \\
\hline AB fonlarından destek sağlanmaktadır & 68 & 3,2 \\
\hline Valilik ve diğer kamu kurumlarından destek sağlanmaktadır. & 101 & 4,7 \\
\hline Fikrim yok. & 977 & 45,8 \\
\hline Toplam & $\mathbf{2 1 3 2}$ & $\mathbf{1 0 0 , 0}$
\end{tabular}

Şekil 5'te katılımcıların kent konseyi bütçesinin kaynağına ilişkin verdikleri cevapların dağılımları görülmektedir.

Şekil: 5

Kent Konseyi Bütçesinin Kaynağı

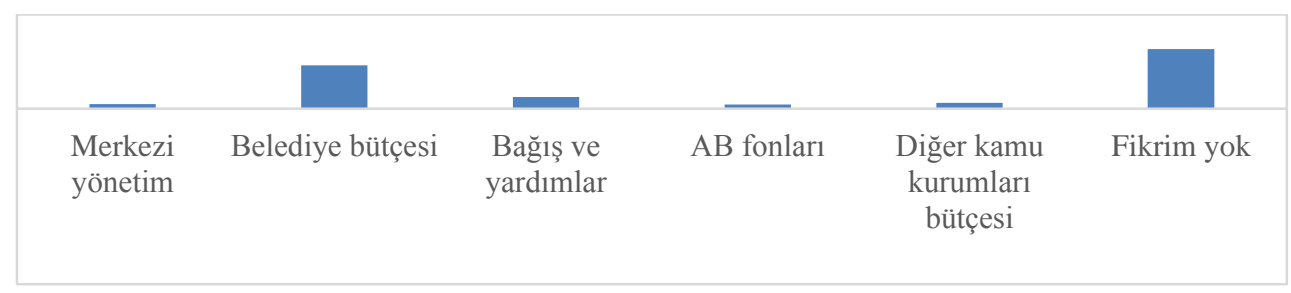




\subsection{Bursa Kent Konseyi’nin Bilinirliğine İliş̧kin Bulgular}

Katılımcılara araştırmanın yapıldığı Bursa kentinde 1995 yılından bu yana varlığını devam ettiren ve bu anlamda Türkiye'deki ilk kent konseyleri arasında yer alan Bursa Kent Konseyi’nin bilinirliğine dair bazı sorular yöneltilmiştir.

Bursa Kent Konseyi'nin Bursa'da yaşayan vatandaşlar tarafindan ne oranda bilindiğini tespit edebilmek için "Bursa Kent Konseyi'ni duydunuz mu?" sorusu sorulmuştur. Tablo 8'den de anlaşılacağı üzere Bursa Kent Konseyi, katılımcıların \%86,4’ü tarafindan duyulmuştur.

Tablo: 8

Bursa Kent Konseyi'ni Duydunuz Mu?

\begin{tabular}{l|c|c} 
& Frekans & \% \\
\hline Evet & 1841 & 86,4 \\
\hline Hayır & 291 & 13,6 \\
\hline Toplam & $\mathbf{2 1 3 2}$ & $\mathbf{1 0 0 , 0}$
\end{tabular}

Anket çalışmasında bireylere Bursa Kent Konseyi'nin çalışma alanları sorulduğunda, ilk sırada \%32,6 oranı ile dezavantajlı gruplara yönelik çalışma yapmak, kentlilik bilincinin oluşturulmasını sağlamak, kültür - sanat faaliyetlerini gerçekleştirmek, belediye faaliyetlerinde etkinliği sağlamaya yardımcı olmak ve kentin öncelikli sorunlarının tartışıldığ bir platform olmak cevabı verilmiştir. Bursa Kent Konseyi'nin çalışma alanının ne olduğu konusunda "fikrim yok" cevabını verenlerin oranı ise \%27,5'tir. Tablo 8 ve Tablo 9 birlikte değerlendirildiğine, Bursa Kent Konseyi'ni duymayanların oranı \%13,6 düzeyindedir fakat Bursa Kent Konseyi'nin çalışma alanları hakkında bilgi sahibi olmayanların oranı $\% 27,5$ 'tir. Bir diğer ifade \%27,5 oranında kişi Bursa Kent Konseyi'ni sadece ismen biliyor ve hangi alanlarda çalışma yaptığı hakkında fikir bile yürütememektedirler.

Tablo: 9

\section{Bursa Kent Konseyi Hangi Alanlarda Çalışmaktadır?}

\begin{tabular}{l|c|c} 
& Frekans & $\mathbf{\%}$ \\
\hline Kadın - genç - engelli vb. gruplara yönelik çalışmalar düzenlemek & 177 & 8,3 \\
\hline Kentlilik bilincinin oluşturulmasını ve geliştirilmesini sağlamak & 224 & 10,5 \\
\hline Kültür- sanat faaliyetlerini gerçekleştirmek & 227 & 10,6 \\
\hline Belediye faaliyetlerinin etkinliğini sağlamaya yardımcı olmak & 302 & 14,2 \\
\hline Kentin öncelikli sorunlarının tartışıldığı bir platform olmak & 172 & 8,1 \\
\hline Hepsi & 695 & 32,6 \\
\hline Adını duydum ancak ne yaptığını bilemiyorum. & 587 & 27,5 \\
\hline Toplam & $\mathbf{2 1 3 2}$ & $\mathbf{1 0 0 , 0}$
\end{tabular}

Şekil 6'da da Bursa Kent Konseyi'nin çalışma alanlarına ilişkin verilen cevaplar görülmektedir. 
Şekil: 6

\section{Bursa Kent Konseyi’nin Çalışma Alanları}

Adını duydum ancak ne yaptığını bilemiyorum.

Hepsi

Kentin öncelikli sorunlarının tartışıldığı bir platform olmak

Belediye faaliyetlerinin etkinliğini sağlamaya yardımci olmak

Kültür- sanat faaliyetlerini gerçekleştirmek

Kentlilik bilincinin oluşturulmasını ve geliştirilmesini sağlamak

Kadın - genç - engelli vb. gruplara yönelik
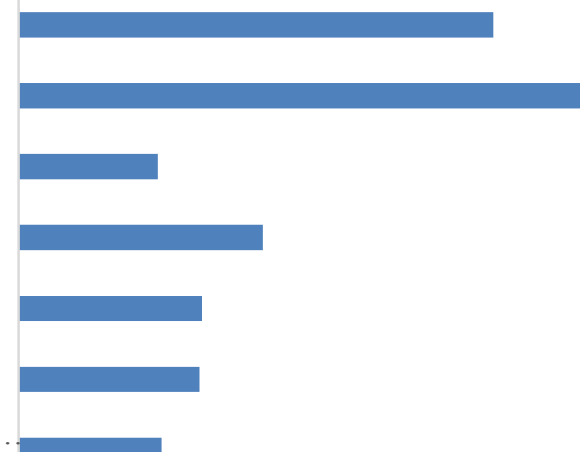

Katılımcıların Bursa Kent Konseyi'nin gerçekleştirdiği çalışmaları ve faaliyetleri takip edip etmediğinin tespit edilmesi amacıyla sorulan soruya \%23,9 oranında "evet" cevabı verilmiştir. Bursa Kent Konseyi'nin faaliyetlerini takip etmeyenlerin oranı ise \% $\% 76,1$ oranındadır. Bu oran Bursa Kent Konseyi açısından önemli bir sorundur ve nedenleri ayrıca araştırılmalıdır.

Tablo: 10

\section{Bursa Kent Konseyi’nin Gerçekleştirdiği Çalışmaları ve Faaliyetleri Takip Ediyor Musunuz?}

\begin{tabular}{l|c|c} 
& Frekans & \% \\
\hline Evet & 509 & 24 \\
\hline Hayır & 1623 & 76 \\
\hline Toplam & $\mathbf{2 1 3 2}$ & $\mathbf{1 0 0 , 0}$
\end{tabular}

Bursa Kent Konseyi'nin gerçekleştirdiği çalışmaları ve faaliyetleri takip ettiğini belirten kişilere (509 kişi) bu çalışmaları hangi kanallarla takip ettikleri sorulmuştur ve birden seçeneği işaretlemelerine bu soruda da izin verilmiştir. Bu soruya cevap verenlerin $\% 45,8$ 'i yerel yazılı ve görsel medya aracılığı ile, \%39,9'u internet aracılığıyla ve \%28,9'u ise afiş - broşür- billboard aracıllığyla cevabını vermişlerdir. 
Tablo: 11

Bursa Kent Konseyi’nin Gerçekleştirdiği Çalışmaları ve Faaliyetleri Hangi Kanallar Aracılığıyla Takip Ediyorsunuz?

\begin{tabular}{l|c|c} 
& Frekans & \% \\
\hline Yerel yazılı ve görsel medya aracılığı ile & 233 & 45,8 \\
\hline İnternet aracılı̆̆ııla (kent konseyi web sitesi, arama motorları, vb.) & 203 & 39,9 \\
\hline Bursa Kent Konseyi toplantılarına katılarak & 37 & 7,3 \\
\hline Afiş, broşür ve billboard aracılı̆̆ı ile & 147 & 28,9 \\
\hline Hepsi & 47 & 9,2 \\
\hline Toplam & $\mathbf{5 0 9}$ & $\mathbf{1 0 0 , 0}$
\end{tabular}

\subsection{Kent Konseylerinin Etkinlik Düzeyine İlişkin Bulgular}

$\mathrm{Bu}$ çalışma kapsamında kent konseylerinin Belediye Kanununun 76. maddesine istinaden çıkartılan Kent Konseyleri Yönetmeliği 6. maddede belirtilen görevleri, yerine getirme düzeyleri vatandaşların bakış açısına göre değerlendirilmiştir. 


\section{Sekil: 7}

\section{Kent Konseylerinin Etkinlik Düzeyini Gösteren Ortalamalar}

Kent Konseyleri, yönetimde saydamlık, katılım, hesap verebilirlik ilkelerinin uygulanmasına katkı sağlamaktadırlar.

Kent konseyleri, çok aktörlü yönetişim anlayışının benimsenmesine katkıda bulunmaktadirlar.

Kent konseyleri kente ilişkin stratejilerin belirlenmesinde ortak aklın oluşturmasına katkıda bulunmaktadırlar.

Kent Konseylerinin yeterli mali kaynaklara sahip olduklarını düşünüyorum.

Kent Konseyinde oluşturulan görüşlerin, yerel halkın isteklerini yansıttığını düşünüyorum.

Yerel kaynakların etkin ve verimli kullanılmasında Kent Konseylerinin yararlı olacağını düşünüyorum.

Kent konseylerinin önemli bir halk katılım mekanizması olarak gerekli olduğunu düşünüyorum.

Demokratik kültürün toplumsal yapıda benimsenmesinde kent konseylerinin yararl olacağını düşünüyorum.

Kentlerin daha yaşanılır hale getirilmesinde kent konseyleri faydalı olacaktır.

Kent konseyleri, kentin, önceliklerinin belirlenmesinde kent yönetimine kolaylık sağlamaktadırlar.

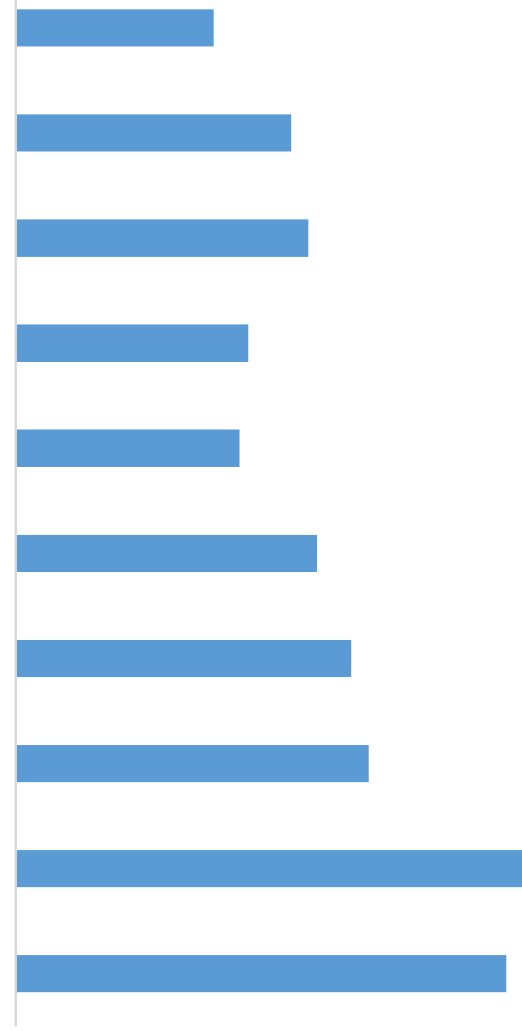

Kent Konseylerinin ilgili yönetmelikte belirtilen görevleri ne oranda yerine getirdiklerinin vatandaş gözüyle irdelenmesi amacıyla geliştirilen anket formunda 1 "kesinlikle katılmiyorum, 2 "katılmıyorum", 3 "fikrim yok", 4 "katıliyorum" ve 5 "kesinlikle katılmıyorum" şeklinde cevaplar bulunmaktadır. Kent konseyleri mekanizmasının etkinliğinin araştırıldığı bu bölümde katılımcıların verdikleri cevapların ortalaması "3,67” düzeyindedir. Bu da göstermektedir ki, alan araştırmasına katılan kişilere göre kent konseyleri ilgili yönetmelikte tanımlanan görevleri etkin bir şekilde yerine getirmektedirler.

Kent konseylerinin yerel düzeyde katılımcı bir mekanizma olarak ne kadar işlevsel olduğunun vatandaşlar gözüyle tespit edilmesine yönelik olarak sorulan sorular şu şekildedir: 
- $\quad$ Kent konseylerinde oluşturulan görüşlerin yerel halkın isteklerini yansıttığını düşünüyorum.

- Yerel demokrasi ve uzlaşma kültürünün benimsenmesinde kent konseylerinin yararlı olduğunu düşünüyorum.

- $\quad$ Kent konseylerinin, kentsel stratejiler ve planların geliştirilmesi sürecinde ortak aklın oluşturulmasına katkıda bulunduklarını düşünüyorum.

- Kent konseylerinin sivil toplumun gelişmesine ve kurumsallaşmasına katkıda bulunduğunu düşünüyorum.

- Kent konseylerinin, kent yönetiminde saydamlık, hesap verebilirlik ilkelerinin uygulanmasına katkı sağladığını düşünüyorum.

Bu sorulara verilen cevaplar aşağıdaki gibidir:

Yerel katılım çerçevesinde ön plana çıkan unsurlardan bir tanesi; yönetim sürecinden etkilenen kişilerin, yönetsel kararlara ilişkin görüşlerinin dikkate alınıp alınmamasıdır. Bunu tespit edebilmek için katılımcılara; "kent konseylerinde oluşturulan görüşlerin yerel halkın isteklerini yansıttığını düşünüyorum.” ifadesine ne oranda katıldıkları sorulmuştur.

Tablo: 12

“Kent Konseylerinde Oluşturulan Görüşlerin Yerel Halkın İsteklerini Yansıttığını Düşünüyorum"

\begin{tabular}{l|c|c} 
& Frekans & $\boldsymbol{\%}$ \\
\hline Kesinlikle Katılmiyorum & 40 & 1,9 \\
\hline Kat1lmiyorum & 198 & 9,3 \\
\hline Fikrim Yok & 736 & 34,5 \\
\hline Kat1lyorum & 842 & 39,5 \\
\hline Kesinlikle Katıliyorum & 316 & 14,8 \\
\hline Toplam & $\mathbf{2 1 3 2}$ & $\mathbf{1 0 0 , 0}$
\end{tabular}

Kent konseylerinde oluşturulan görüşlerin yerel halkın isteklerini yansıttı̆̆ını düşünenlerin oranı \%54,3'dür. $\mathrm{Bu}$ oran, diğer sorulara verilen cevapların altında kalmaktadır. Kent konseylerinin görevlerine ilişkin olarak anket formuna eklenen bu soru, katılımcıların verdikleri cevaplar açısından en düşük ortalamaya sahiptir. Bir diğer ifade ile katılımcıların en az destekledikleri ve bu anlamda kent konseylerinin görevlerini yerine getirme açısından en düşük puanın verildiği sorudur (5 tam puan üzerinden 3,53$)$. Bu durum aşağıdaki Şekil 8'de de görülmektedir. 
Şekil: 8

Kent Konseylerinin Yerel Halkın İsteklerini Yansıtması

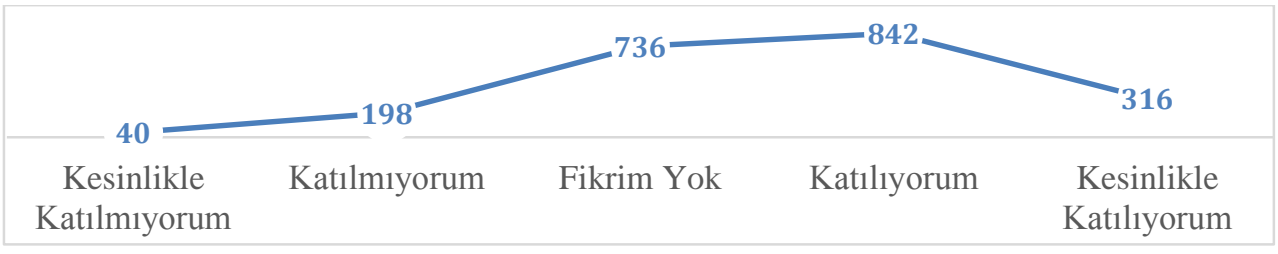

Alan araştırması kapsamında anket formuna Kent Konseyleri Yönetmeliğinin 6/ç fikrasında belirtilen "yerellik ilkesi çerçevesinde katılımcılığı, demokrasiyi ve uzlaşma kültürünü geliştirmek" şeklinde tanımlanan görevinin ne oranda yerine getirildiğinin tespit edilmesi amaciyla sorulan soruya verilen cevaplar Tablo 13'te görülmektedir. Kent konseyleri belirtilen bu görevi, araştırmaya katılan katılımcıların \%60,3'üne göre etkin bir şekilde yerine getirmektedirler. Bu durum Şekil 9'da da görülmektedir.

Tablo: 13

\section{"Yerel Demokrasi ve Uzlaşma Kültürünün Benimsenmesinde Kent Konseylerinin Yararlı Olduğunu Düşünüyorum”}

\begin{tabular}{l|c|c} 
& Frekans & \% \\
\hline Kesinlikle Katılmıorum & 15 & 0,7 \\
\hline Katılmıyorum & 109 & 5,1 \\
\hline Fikrim Yok & 722 & 33,9 \\
\hline Kat1liyorum & 910 & 42,7 \\
\hline Kesinlikle Katıliyorum & 376 & 17,6 \\
\hline Toplam & $\mathbf{2 1 3 2}$ & $\mathbf{1 0 0 , 0}$
\end{tabular}

Şekil: 9

Kent Konseylerinin Yerel Demokrasi ve Uzlaşma Kültürünü Oluşturmadaki Rolü

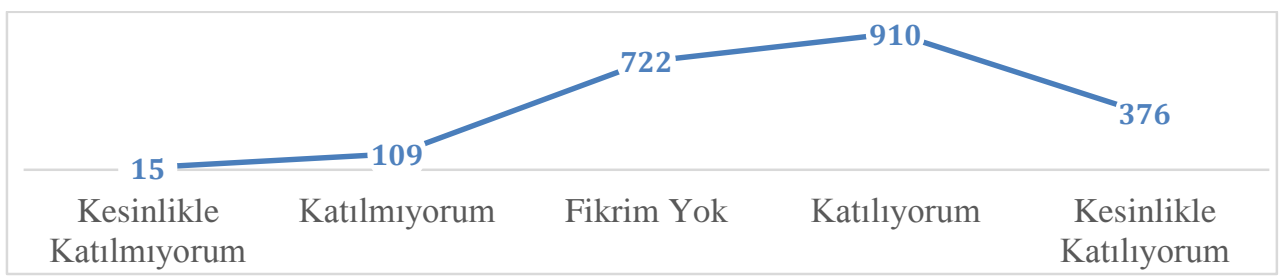

Kent Konseyleri Yönetmeliği 6. maddesinin c fikrasında belirtilen "kente ilişkin temel stratejiler ve faaliyet planlarının belirlenmesinde, uygulama ve izleme süreçlerinde tüm kenti kapsayan ortak bir aklın oluşturulmasına katkıda bulunmak" görevinin kent konseyleri tarafından ne oranda yerine getirildiğinin analiz edilmesi amacıyla sorulan soruya katılımcıların verdikleri cevaplar Tablo 14'te görülmektedir. 
Tablo: 14

"Kent Konseylerinin, Kentsel Stratejiler ve Planların Geliştirilmesi Sürecinde Ortak Aklın Oluşturulmasına Katkıda Bulunduklarını Düşünüyorum”

\begin{tabular}{l|c|c} 
& Frekans & \% \\
\hline Kesinlikle Katılmıyorum & 34 & 1,6 \\
\hline Katılmıyorum & 141 & 6,6 \\
\hline Fikrim Yok & 733 & 34,4 \\
\hline Kat1liyorum & 883 & 41,4 \\
\hline Kesinlikle Kat1liyorum & 341 & 16,0 \\
\hline Toplam & $\mathbf{2 1 3 2}$ & $\mathbf{1 0 0 , 0}$
\end{tabular}

Tablo 14'te ve Şekil 10'da da görüldüğü üzere alan araştırmasına katılan katılımcıların \%57,4’ü kent konseylerinin, kentsel stratejiler ve planların geliştirilmesi sürecinde ortak aklın oluşturulmasına katkıda bulunduklarını düşünmektedirler.

Şekil: 10

Kent Konseylerinin, Kentsel Stratejiler ve Planların Geliştirilmesi Sürecinde Ortak Aklın Oluşturulmasına Katkısı

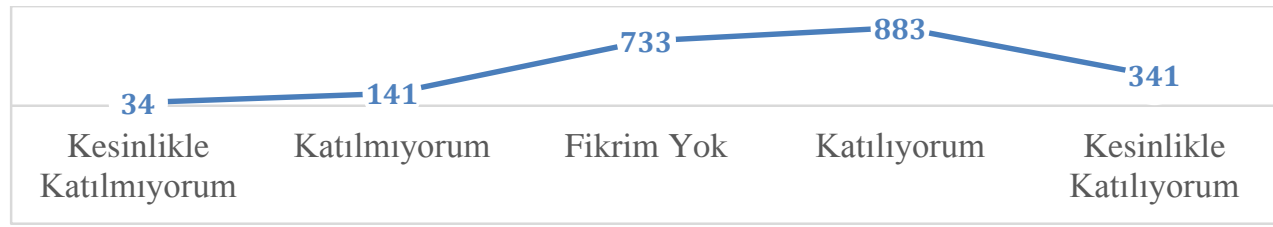

Kent Konseyleri Yönetmeliğinin 6/g fikrasında belirtilen "sivil toplumun gelişmesine ve kurumsallaşmasına katkıda bulunmak" görevini ne düzeyde yerine getirdiğini tespit edebilmek amacıyla sorulan soruya katılımcıların \%60,4’ü olumlu yönde cevap vererek, kent konseylerinin bu anlamda görevini yerine getirdiğini belirtmişlerdir (Tablo 15 ve Şekil 11).

Tablo: 15

“Kent Konseylerinin Sivil Toplumun Gelişmesine ve Kurumsallaşmasına Katkıda Bulunduğunu Düşünüyorum"

\begin{tabular}{l|c|c} 
& Frekans & \% \\
\hline Kesinlikle Katılmıorum & 39 & 1,8 \\
\hline Katılmıyorum & 130 & 6,1 \\
\hline Fikrim Yok & 676 & 31,7 \\
\hline Katıliyorum & 900 & 42,2 \\
\hline Kesinlikle Katıliyorum & 387 & 18,2 \\
\hline Toplam & $\mathbf{2 1 3 2}$ & $\mathbf{1 0 0 , 0}$
\end{tabular}


Şekil: 11

Sivil Toplumunun Gelişmesinde Kent Konseylerinin Rolü

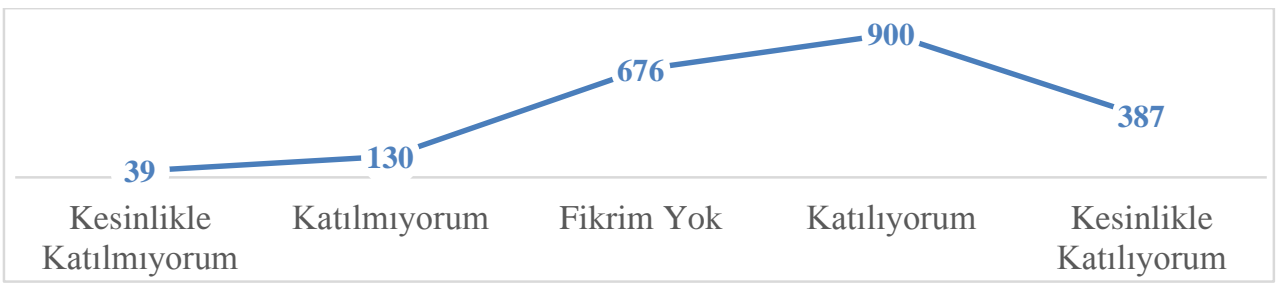

Yeni kamu yönetimi anlayışındaki temel yönetim politikalarından bir tanesi yönetim süreçlerinin saydam olması, politikalar ve uygulamalar hakkında istenilen zamanında yetkili kurum ve kişilere hesap verilebilmesidir. Söz konusu unsura Kent Konseyleri Yönetmeliğinin 6/h fikrasında vurgu yapılmaktadır. Vatandaşlara göre kent konseylerinin kentsel yönetim süreçlerindeki saydamlık ve hesap verebilirlik ilkelerinin uygulanmasına imkân verici çalışmalar yapıp yapmadığını tespit edebilmek için anket formunda bu hususa yer verilmiştir.

Tablo: 16

"Kent Konseylerinin, Kent Yönetiminde Saydamlık, Hesap Verebilirlik İlkelerinin Uygulanmasına Katkı Sağladığını Düşünüyorum”

\begin{tabular}{l|c|c} 
& Frekans & \% \\
\hline Kesinlikle Katılmıyorum & 59 & 2,8 \\
\hline Katılmyorum & 158 & 7,4 \\
\hline Fikrim Yok & 826 & 38,7 \\
\hline Kat1liyorum & 764 & 35,8 \\
\hline Kesinlikle Katıliyorum & 325 & 15,2 \\
\hline Toplam & $\mathbf{2 1 3 2}$ & $\mathbf{1 0 0 , 0}$
\end{tabular}

Tablo 16 'da da görüldüğü üzere katılımcıların \%51'i, kent konseylerinin kent yönetiminde saydamlık ve hesap verebilirlik ilkelerinin uygulanmasına katkı sağlamaktadır. $\% 38,7$ 'si ise bu konuda herhangi bir fikir beyan etmemişlerdir (Bakınız Şekil 12). 
Şekil: 12

Kent Konseylerinin, Kent Yönetiminde Saydamlık, Hesap Verebilirlik İlkelerinin Uygulanmasına Katkı Sağlamaları

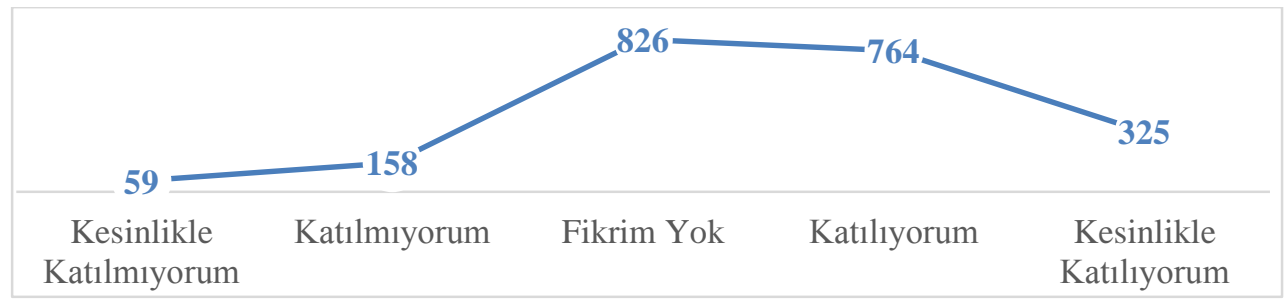

\section{Sonuç}

Vatandaşların kentsel yönetim süreçlerine daha aktif katılabilmeleri, kent yönetiminde söz sahibi olabilmeleri, kendilerini ilgilendiren konularda fikirlerini dile getirebilmeleri ve kentteki farklı fikirlerin tartışılabildiği, bir diğer ifade ile kentin ortak aklı olması bağlamında önemli roller yüklenen kent konseylerinin; gerek yasal - yönetsel yapıları gerek çalışma sistemleri açısından vatandaşlar tarafindan ne kadar bilindiğinin vatandaşlar gözüyle irdelenmesi ihmal edilmiş bir olgudur. Ülkemizde çeşitli yönetsel mekanizmalar, belirlenen hedefler ve öncelikler doğrultusunda bireylerin refahı, huzuru ve “iyiliği”" için kurgulanmış ve oluşturulmuştur. Fakat bu kurgulanma sürecinde olayın diğer tarafına yani vatandaşların tarafına geçilerek söz konusu mekanizmaların nasıl algılandığına ilişkin bir değerlendirme genellikle ihmal edilmiştir. Çalışma bu anlamda önem arz etmektedir. Çalışmanın sonuçları şu şekilde özetlenebilir:

- Alan araştırmasına katılan kişilerin $\% 55,5$ ’i orta öğretim düzeyindedir, \%35,3'ü asgari ücret ile 2000 TL arasında değişen bir gelire sahiptir, \%60,4'ü evlidir \%92,8'i herhangi bir STK'ya üye değildir.

- Araştırmaya katılan kişilerin \%73,2’si (2132 kişi) daha önceden kent konseyleri adlı kurumun adını duymuşlardır. Bir diğer ifade ile kent konseyleri mekanizmasından haberdardırlar. Kent konseyinin varlığından haberdar olan 2132 kişiye Bursa Kent Konseyi kurumunu daha önceden duyup duymadıkları sorulduğunda ise Bursa Kent Konseyi’nin varlığından daha önceden haberdar olan kişilerin oranı \%86,4’tür (1841 kişi).

- Araştırmaya katılan kişilerin büyük bir kısmı kent konseylerinin çalışma yapısı, yasal - yönetsel statüsü konusunda bilgi sahibi değildir. Zira kent konseylerinin ilgili belediyeler tarafından kurulmalarının zorunlu olduğu bilenlerin oranı \%18,8'dir ve Türkiye'deki tüm illerde ve belediyelerde bulunmadığı bilen kişilerin oranı da \%35,5 düzeyindedir. Katılımcılara, kent konseyi genel kurulunun kimlerden oluştuğu sorulduğunda ise \%42,8 oranında fikrim yok cevabı verilmiştir. Son olarak araştırmaya katılan 
kişilerin sadece \%33,4’ü kent konseylerinin bütçelerinin kaynağının belediyeden aktarılan fonlardan oluştuğu bilmektedir.

Kent konseyleri ilgili alan araştırmasının ikinci bölümünde araştırmaya katılan kişilerin, kent konseylerini, Belediye Kanunu'nun 76. maddesine istinaden çıkartılan Kent Konseyleri Yönetmeliği'nde 6. maddede belirtilen görevleri yerine getirmedeki etkinlik düzeylerinin değerlendirilmesi hedeflenmiştir. Kent konseyleri mekanizmasının etkinliğinin araştırıldığı bu bölümde katılımcıların verdikleri cevapların ortalaması "3,67” (5 tam puan üzerinden) düzeyindedir. Bu da göstermektedir ki, alan araştırmasına katılan kişilere göre kent konseyleri, ilgili yönetmelikte tanımlanan görevleri etkin bir şekilde yerine getirmektedirler. Bu bölümdeki araştırma verileri kısaca şu şekilde değerlendirilebilir:

- Alan araştırması sonuçlarına göre kent konseylerinin en etkin olarak yerine getirdiği işlev; "kentlerin daha yaşanılır hale getirilmesi" sürecine katkı sağlayacağı şeklindedir (5 tam puan üzerinden 3,89 ortalamaya sahiptir.). Katılımcıların \%71,4’̈̈ kentlerin daha yaşanılır hale gelmesinde kent konseylerinin yapacağı çalışmaların faydalı olacağını düşünmektedirler. Buna göre alan araştırmasına katılan kişilere göre kent konseyleri kurumu, Kent Konseyleri Yönetmeliği'nin 7/a maddesinde belirtilen; “... aktif katılım ve çözümde ortaklık ilkelerinin bütünlüğünde, kentlerin yaşanabilir bir geleceğe taşınmasına katkıda bulunmak" olarak belirtilen çalışma ilkesini en etkin olarak yerine getirmektedirler.

- Alan araştırması sonuçlarına göre kent konseylerinin en az yerine getirdiği işlev ise; "yerel halkın isteklerini yansıtan bir mekanizma" olmalarıdır (5 tam puan üzerinden 3,53 ortalamaya sahiptir.). Bu işlev Kent Konseyleri Yönetmeliği’nin temel dayanağı olan yönetişim anlayışına dayalı, çeşitli toplum kesimlerinin kent yönetimine katkıda bulunmaları çerçevesinde şekillenen yapısına vurgu yapmaktadır. Kent konseylerinde oluşturulan görüşlerin yerel halkın isteklerini yansıttığını düşünenlerin oranı \%54,3'dür. Alan araştırmasına katılan kişilere göre ise kent konseylerinin bu işlevi yerine getirmesinde sorunlar bulunmaktadir.

- Netice Bursa'da yaşayan vatandaşlara göre kent konseylerini, yasal mevzuattaki tanımlanan işlevlerini yerine getirmeleri bağlamında başarılı olarak değerlendirmek mümkündür. Yine Bursa'da yaşayan vatandaşlar tarafından ismen de olsa kent konseylerinin bilinirlikleri de oldukça yüksek bir düzeydedir.

Alan araştırmasının sonuçlarına göre, çalışmaya katılan kişiler kent konseyleri kurumundan haberdardırlar ve konseyin çalışmalarını etkin bir şekilde yerine getirdiğini düşünmektedirler. Fakat bu kişiler, kent konseyini sadece ismen bilmektedirler; konseyin yasal yapısını, çalışma sistemini, kimlerden oluştuğunu, bütçesinin kaynağı hakkında bilgi sahibi değillerdir. 
$\mathrm{Bu}$ çalışmada da tespit edilen oldukça önemli bir konu vardır ki bu da Türkiye'deki diğer kent konseylerinin ve belki de Türkiye'deki demokratik yapının en önemli sorunlarından birisidir. Bireyin yönetsel mekanizmalara dâhil olabilmesinin önünü açıcı kurumlar ortaya konsa da genellikle bu mekanizmalara aktif olarak katılan kişilerin sayısı sınırlı olmaktadır. Ayrıca bireyler, kent konseyleri adlı bir kurumun varlığından haberdardırlar fakat bu kurumun yasal - yönetsel yapısı hakkında yeterince bilgi sahibi değillerdir. Bu sorun Türk demokrasi kültürünün belki de en önemli problemleri arasında yer almaktadir.

Kent konseyleri özelinde Bursa kentinde bu yönde çalışmalar yaparak Bursa halkının daha aktif bir şekilde yönetsel süreçlere katılımını teşvik edici projelere adım atması, Türkiye'deki diğer kent konseyleri için bir örnek teşkil edecektir.

\section{Kaynaklar}

Bulut, T. (2013), Kent Konseyleri, Bursa: Ekin Yayınevi.

Bursa Büyükşehir Belediyesi (2008), Bursa Yerel Gündem 21, Bursa: Bursa Yerel Gündem 21 Yayın1.

Emrealp, S. (2004), Yerel Gündem 21 Uygulamalarına Yönelik Kolaylaştırıcı Bilgiler El Kitabı, İstanbul: IULA-EMME Yayını.

Karakurt Tosun, E. \& E.B. Keskin (2015), "City Councils as a Means of Local Participation in Turkey during the EU Membership Process: the Investigation of the Awareness of the Bursa City Council”, Yönetim ve Ekonomi Araştırmaları Dergisi, 13(3), 363-376. Doi: http://dx.doi.org/10.11611/JMER713.

Keskin, E.B. (2014), "Belediyeler ve Kent Konseyleri: Temsilden Katılıma”, Mimar ve Mühendis Dergisi, 76, 56-58.

Soygüzel, H. (2015) "Kent Konseylerinin Arasında İletişim ve İşbirliği: Türkiye Kent Konseyleri Birliği Örneği”, Paradoks: Ekonomi Sosyoloji ve Politika Dergisi (e-dergi), 11 (Özel Say1 2), 63-82;

<http://www.paradoks.org/components/articles/articles/show/4272EVA115239261015>, 07.01.2016.

Soygüzel, H. (2012) “Kent Konseyleri Ulusal Rapor”, 3. Ulusal Kent Konseyleri Birliği Buluşması, Türkiye Kent Konseyleri Birliği.

UN (1991), "World Commission on Environment and Development", Our Common Future, Oxford University Press.

Yazıcıŏlu, Y. \& S. Erdoğan (2004), SPSS Uygulamalı Bilimsel Araştırma Yöntemleri, Ankara: Detay Yayınları. 
Karakurt Tosun, E. \& E.B. Keskin \& E. Selimoğlu (2016), "Yerel Düzeyde Katılımcı Mekanizmalar Olarak Kent Konseylerinin Bilinirlilik ve Etkinlik Düzeylerinin Analizi: Bursa Örneği”, Sosyoekonomi, Vol. 24(28), 85-107. 